\title{
Strategi Pendidik Anak Usia Dini Era Covid-19 Dalam Menumbuhkan Kemampuan Critical Thinking
}

\author{
Mutmainnah \\ STKIP Bina Bangsa Getsempena \\ email: mumutbukhari@gmail.com
}

DOI: $10.31849 /$ paud-lectura.v\%vi\%i.4982

Received 22 September 2020, Accepted 22 September 2020, Published 1 Oktober 2020

\begin{abstract}
Abstrak
Penelitian ini bertujuan untuk melihat strategi pendidik yang idealnya dalam pembelajaran jarak jauh (daring), diakrenakan disaat pandemic Covid-19 muncul semuanya telah berubah, pendidik membuat strategi baru dalam menumbuhkan critical thinking pada anak usia dini di saat pandemi yang melanda seluruh dunia, atau yang disebut dengan Covid-19. Penelitian ini dilakukan dengan pendekatan kualitatif dalam bentuk metode studi kasus untuk memperoleh pengetahuan tentang strategi pendidik dalam mengembangkan kemampuan critical thinking pada anak usia dini. Pemilihan subjek . pengumpulan data dilakukan dengan penggunaan model interaktif dengan analisis data, yaitu reduksi data, penyajian data, penarikan kesimpulan dan verifikasi. Hasil penelitian menunjukkan bahwa pertama, selama pandemic Covid-19 anak belajar di rumah dengan menggunakan pembelajaran jarak jauh (daring); kedua, adanya strategi dari pendidik PAUD dalam mengembangkan kemampuan critical thinking selama anak belajar melalui jarak jauh (Daring) yaitu anak diajak untuk tetap bermain sambal belajar meskipun di rumah, memberikan pemahaman bahwa anak wajib memakai masker jika berada di luar rumah, anak harus menggunakan hand sanitizer atau mencuci tangan disaat bermain dan setelah bermain, menjelaskan kepada anak mengapa tidak dapat melakukan kegiatan bermain di luar rumah.
\end{abstract}

Kata Kunci : strategi pendidik; anak usia dini; critical thinking

\begin{abstract}
This study aims to look at educators' strategies, ideally in distance learning (online), because when the Covid-19 pandemic appears everything has changed, educators make new strategies in fostering critical thinking in early childhood during a pandemic that hits the whole world, or which is called Covid-19. This research was conducted with a qualitative approach in the form of a case study method to gain knowledge about educators' strategies in developing critical thinking skills in early childhood. Subject selection. Data collection was carried out by using an interactive model with data analysis, namely data reduction, data presentation, drawing conclusions and verification. The results showed that first, during the Covid-19 pandemic children studied at home using distance learning (online); second, there is a strategy from early childhood educators in developing critical thinking skills as long as children learn via long distance (online), that is, children are invited to continue playing while learning even at home, providing an understanding that children are required to wear masks when outside the home, children must use hands sanitizer or washing hands while playing and after playing, explaining to children why they cannot play activities outside home.
\end{abstract}

Keywords: educators strategy; early childhood; critical thinking 


\section{PENDAHULUAN}

Pandemi covid-19 merubah semua aktivitas dalam lembaga PAUD, anak yang biasanya belajar tatap muka di sekolah, kini harus melakukan segala aktivitasnya di rumah. Aktivitas pendidikan yang sangat lekat dengan interaksi yang melibatkan banyak orang; pembelajaran yang biasanya dilakukan antara pendidik dan peserta didik di sekolah dengan bertatap muka, kini telah berubah dikarenakan pandemi covid-19, interaksi secara tatap muka ditiadakan (social distancing) dan diganti dengan aktivitas pembelajaran jarak jauh (daring) dengan memanfaatkan media internet. Hal ini dikarenakan adanya pembatasan social dan mencegah penularan virus Covid19, hal tersebut tidak hanya berlaku pada Lembaga PAUD, tetapi berlaku untuk seluruh jenjang pendidikan dimulai dari pendidikan anak usia dini sampai seluruh jenjang pendidikan, baik menengah maupun pendidikan tinggi. Pembelajaran yang semula tatap muka berganti dengan pembelajaran jarak jauh (daring), pembelajaran daring biasanya dilakukan dengan menggunakan zoom meeting maupun google meet.

\begin{tabular}{llr}
\multicolumn{4}{r}{ Pola pembelajaran pada anak } \\
usia dini & didasari & dengan \\
pengembangan & kurikulum & secara \\
konkret yang & berisi & rencana
\end{tabular}
pembelajaran melalui bermain dan dilakukan dengan keterlibatan aktif oleh pendidik dan peserta didik (Permatsari, Dewiana, Rohaeti, Euis Eti Sharina dan Westhisi, 2019). Dikarenakan adanya pandemi Covid-19 segala aktivitas bermain sambil belajar anak dibantu oleh orang tua, dan semua aktivitas anak dilakukan di rumah bersama orang tua. Pemberian stimulasi perkembangan untuk perkembangan kognitif, bahasa, fisik motorik, sosial emosional, agama dan moral serta seni harus dilakukan di rumah masing-masing peserta didik. Pemberian stimulasi terhadap perkembangan anak usia dini dilakukan secara efektif dan efisien oleh pendidik PAUD menggunakan beragam media sebagai sarana pembelajaran dengan prinsip bahwa aktivitas utama anak bermain sambil belajar (Yunita, H., Meilanie, S. M., \& F. 2019). Bermain merupakan dunia anak, setiap anak selalu ingin bermain, karena dengan bermain anak merasa rileks dan tenang (Roger, Cosby S, dan Janet K, 1995). Bermain dapat digunakan anak-anak untuk menjelajahi dunianya dan mengembangkan kreativitas anak, dengan bermain anak memiliki kemampuan untuk memahami konsep secara ilmiah tanpa paksaan (Singer, 2004).

Perkembangan kognitif sebagai salah satu perwujudan suasana untuk berkembangnya kematangan proses berfikir dalam konteks bermain pada anak dan juga merupakan perkembangan yang paling utama dan harus di stimulasi dengan baik (Ayu, C. 2016), perkembangan kognitif mempunyai beberapa indikator yang terbagi dalam tiga lingkup aspek perkembangan yaitu pertama, belajar dan pemecahan masalah; kedua, berfikir kritis dan logis; ketiga, berfikir simbolik . Sedangkan untuk aspek perkembangan bahasa memiliki tiga lingkup aspek perkembangan yaitu pertama, 
memahami bahasa; kedua, mengungkapkan bahasa dan ketiga, keaksaraan (Permendikbud, 2014). Perkembangan setiap anak memiliki pola yang sama, walaupun kecepatannya berbeda, setiap anak mengikuti pola yang dapat diramalkan dengan cara dan kecepatannya sendiri (An Verburg, 2019).

Perkembangan kognitif anak dapat tercermin dalam pertumbuhan yang cepat pada penguasaan ide-ide yang ada pada anak (Fardiah, Murwani, Santosa dan Dhieni, 2020). Dalam mengembangkan perkembangan kognitif anak-anak memiliki dorongan kuat untuk mencari tahu tentang banyak hal, namun sangat disayangkan ketika orang tua menganggap bahwa anak yang memiliki kemampuan kognitif yang baik maka akan dianggap anak yang cerdas dan berintelektual baik (Joni, 2016). Oleh karenanya hampir di semua lembaga PAUD di Indonesia menerapkan porsi yang cukup besar dalam kegiatan pengembangan kemampuan kognitif (Tatminingsih, 2019). Sementara itu Dodge, Diane dan Colker, Laura J menyatakan bahwa perkembangan kognitif meliputi beberapa kemampuan, yaitu: 1) to acquire learning dan problem solving skills; 2) to expand logical thinking skills; 3) to acquire concepts and information leading to a fuller understanding of the immediate world; 4) to demonstrate skills in make believe play; 5) to expand verbal communication skills; 6) to develop beginning reading skills; and 7) to acquire beginning reading skills (Diane T Dodge and Laura J Colker, 2001).
Pelaksanaan pembelajaran selama pandemi dilakukan oleh pendidik yaitu guru PAUD sebagai perencana kegiatan dan penilai hasil pembelajaran. Sementara untuk pelaksanaan pembelajaran diperankan atau dilakukan oleh orang tua (pendidik) di rumah masing-masing bermain sambil belajar tetap menjadi prinsip utama.

\section{METODE}

Penelitian ini menggunakan pendekatan kualitatif dengan metode penelitian studi kasus. Creswell menyatakan bahwa studi kasus merupakan metode penelitian yang menyelediki secara detail suatu kejadian, suatu kegiatan, kegiatan yang dilakukan sekelompok individu serta aktivitas informan (Creswell, 2015). Di saat peneliti mewawancarai kepala sekolah TK- Al munawwarah, anakanak banyak yang terus menerus tidak ingin bermain sambil belajar di rumah, dikarenakan mereka ingin bermain outdoor dan ingin bermain dengan teman-temannya di sekolah, disini peneliti melihat bahwa pendidik dan orang tua kurang dalam mengasah critical thinking anak, karena anak belum bisa memahami apa yang terjadi saat ini. Dengan adanya penelitian ini diharapkan peneliti dapat mendeskripsikan strategi pendidik anak usia dini era Covid-19 dalam menumbuhkan dan mengembangkan kemampuan critical thinking anak. Selanjutnya, hasil temuan penelitian dideskripsikan dengan bahasa yang tepat dan sistematis sesuai dengan fakta yang ada di lapangan (Norman K. Denzin \& Yvonna S. Lincoln, 2009). 
Penelitian dilakukan di TK AlMunawarrah, adapun waktu pelaksanaan penelitian yaitu pada bulan Juli dan agustus 2020, ketika diberlakukannya larangan untuk berkumpul (social distancing) seluruh pelaksanaan pembelajaran di seluruh jenjang pendidikan dihimbau untuk dilakukan dari rumah (daring) peserta didik. Adapun yang menjadi subjek penelitian ini yaitu anak pada kelompok A di TK Al-Munawarrah, pendidik memberikan stimulasi perkembangan dan orang tuanya masing-masing menyampaikan kepada anak di rumah kemudian assessment pembelajaran dapat dilakukan melalui media sosial (WhatsApp) grup kelompok A TK AlMunawarrah.

Wawancara dan dokumentasi merupakan teknik yang paling utama dalam penelitian ini. Peneliti menggunakan teknik wawancara dan dokumentasi karena adanya pembatasan sosial dan physical distancing yang membatasi peneliti untuk menggunakan Teknik pengumpulan data yang lainnya. Data yang terkumpul selanjutnya dianalisis dengan menggunakan langkah-langkah yaitu reduksi data, penyajian data, penarikan kesimpulan dan verifikasi.

\section{HASIL DAN PEMBAHASAN}

Strategi dalam merngembangkan kognitif anak merupakan sebagai salah satu aspek penting perkembangan pada anak usia dini yang harus dikembangkan pendidik di seluruh Lembaga PAUD, khususnya di Aceh. TK Al-Munawarrah selaku lembaga pendidikan anak usia dini yang memberikan layanan untuk anak usia lima sampai enam tahun juga secara interaktif dan menyenangkan mengikuti pedoman perkembangan anak yang telah ditentukan oleh standar nasioanl maupun permendikbud 137. Adapun standar tingkat pencapaian perkembangan anak (STTPA) terdiri dari nilai agama dan moral, fisikmotorik, kognitif, bahasa, social emosional dan seni (Jawati, 2013).

Pendidik menstimulasi anak pada perkembangan kognitif di TK AlMunawarrah berpedoman pada indikator capaian perkembangan yang telah ditetapkan Permendikbud nomor 137 tahun 2014 tentang standar nasional PAUD. Perkembangan kognitif dalam standar PAUD antara lain anak diminta untuk memecahkan masalah, critical thinking dan berfikir simbolik dengan indikator capaian masing-masing perkembangan yang berbeda. Berikut indikator perkembangan kognitif dan lingkup perkembangannya serta indikator masing- masing lingkup perkembangan sesuai dengan Permendikbud 137 tahun 2014 sebagai berikut:

Berdasarkan lingkup perkembangan kognitif dan indikator capaiannya yang telah dikemukakan, selanjutnya peneliti menentukan lingkup perkembangan critical thinking yang akan menjadi fokus utama dalam proses pengamatan saat anak telah melakukan pembelajaran di rumah, strategi pendidik PAUD di rumah yang diwakili oleh orang tua dapat membantu pendidik di sekolah dalam mengembangankan kemampuan critical thinking. Walaupun tidak semua orang tua dapat memberikan stimulasi 
perkembangan seperti komunikasi yang disampaikan oleh guru PAUD. Irma, Nisa dan Sururiyah menyatakan bahwa keterlibatan pendidik di rumah (orang tua) dalam pembelajaran akan dipengaruhi oleh pemahamannya dalam status, bentuk keluarga, tahap perkembangan keluarga dan model peran orangtua (Irma, Nisa \& Sururiyah, 2019).

Adanya pandemi coronavirus disease atau covid-19 menyebabkan pemberian stimulasi perkembangan di TK Al-Munawarrah mengalami perubahan dari sebelumnya bertatap muka antara pendidik dan peserta didik melalui kegiatan bermain sambil belajar kini berubah menjadi antara orang tua dan peserta didik. Hal ini dikarenakan kebijakan pemerintah (kemendikbud) melalui surat edaran nomor 4 tahun 2020 tentang pelaksanaan kebijakan pendidikan dalam masa pandemi atau darurat Covid-19. Surat edaran yang memuat kebijakan tersebut merubah kebijakan yang sebelumnya ada. Kegiatan belajar mengajar yang sebelumnya tatap muka berubah menjadi pembelajaran jarak jauh (daring) di seluruh jenjang Pendidikan, dimulai dari PAUD, sekolah dasar, Pendidikan menengah serta perguruan tinggi. Berubahnya aturan ini membuat pendidikan juga berdampak pada strategi pendidik dalam memberikan materi dan pembelajaran untuk peserta didik.

Kegiatan pembelajaran di rumah digantikan oleh orang tua yang menjadi pendidik, pastinya menjadi sesuatu yang unik dan menantang. Pelaksanaan pembelajaran di rumah dimana orang tua berperan sebagai pendidik bukanlah suatu yang mudah, karena sekolah memiliki rpph khusus, orang tua diarahkan tidak boleh hanya berfokus pada salah satu STPPA saja, akan tetapi pembelajaran harus diarahkan pada pemberian pengalaman belajar yang bermakna bagi anak. Fokus materi yang dituntut pada anak disesuaikan dengan standar kompetensi dan kompetensi dasar dilakukan penyesuaian dimana fokusnya pada arah pendidikan kecakapan hidup antara lain mengenai penyebaran Covid-19 ke beberapa negara, khususnya Indonesia. Pada aktivitas dan tugas pembelajaran peserta didik yang sebelumnya kaku yaitu harus sesuai tuntutan standar kompetensi yang ada, dengan Kebijakan ini dilakukan reorientasi pembelajaran dengan aktivitas yang bervariasi antarsiswa tergantung minat dan kondisi masingmasing dengan mempertimbangkan kesenjangan akses/fasilitas belajar tempat masing-masing peserta didik. Begitu juga dengan produk hasil belajar jika sebelumnya berfokus pada penguasaan pengetahuan, keterampilan dan sikap dengan memberikan bintang pada anak, kebijakan ini mengubah hal tersebut pada umpan balik yang bersifat kualitatif yang berguna kepada pendidik/guru untuk lebih banyak mendeskripsikan hasil belajar anak selama di rumah.

Semua kebijakan pemerintah mengenai pelaksanaan pendidikan selama masa Covid-19 sangat sesuai dengan prinsip-prinsip dalam pembelajaran di jenjang PAUD, pemberian materi baik tema maupun subtema dapat disesuaikan dengan 
menggunakan kriteria kedekatan, kesederhanaan, kemenarikan dan keinsidentalan. Anak usia dini juga dikenalkan dengan materi yang berkaitan dengan Covid-19, materi tersebut pada awalnya tidak ada dalam rencana pembelajaran semester di TK Al-Munawarrah, namun dengan berpedoman pada prinsip pemilihan tema yang disesuaikan dengan keadaan pandemic maka tema ini dimunculkan.

Pendidik anak usia dini dalam memberikan stimulasi perkembangan kepada anak di masa pandemi ini bekerja sama dengan orang tua, karena peran pendidik di sekolah telah dialihkan kepada orang tua di rumah. Dengan adanya hal ini maka orang tua juga masuk dalam kategori pendidik anak usia dini, orang tualah yang sekarang mengambil peran penting di rumah dalam merangsang perkembangan anak. Wahy menyatakan bahwa keluarga menjadi sekolah pertama bagi anak sebelum anak lanjut keppendidikan formal (Wahy, 2012). Hewi, Saleh dan Wahyuni menyatakan bahwa pengetahuan dan keterampilan yang berbeda antara orang tua yang satu dan lainnya akan berpengaruh pada cara pengasuhan atau cara mendidik anak (Hewi, Saleh dan Wahyuni, 2019). Sehingga untuk keseragaman dalam pemberian stimulasi bagi anak usia diperlukan kerjasama antara pendidik dengan orang tua anak di saat pandemi Covid-19 ini. pendidik sebagai perencana dan penilai hasil pembelajaran sedangkan orang tua di rumah sebagai pelaksana rencana pembelajaran dari guru PAUD.
Oleh karena itu dibutuhkan komunikasi yang otenting dan berkesinambungan antara pendidik dan orang tua agar strategi pendidik dalam mengasah critical thinking anak selama pandemic ini dapat berjalan lancar, dan anak dapat memahami situasi yang dialaminya saat ini. Pendidik melakukan assessment setiap harinya untuk mengevaluasi perkembangan kognitif anak setiap harinya melali penilaian yang dilaporkan oleh orang tua melalui grup WhatsApp.

Hasil pembelajaran akan dilaporkan oleh orang tua selaku pendidik PAUD di rumah melalui rekaman kegiatan dan dokumentasi hasil kerja anak selama proses pembelajaran melalui media social (WhatsApp) grup satuan PAUD. Hasil pembelajaran atau assessment anak harus dilakukan secara outentik dan terstruktur (Dewi, Iratna dan Suryana, D, 2020).

Hasil rekaman atau dokumentasi hasil karya dikirim oleh orang tua peserta didik, selanjutnya dianalisis dan pendidik memberikan bintang sesuai dengan kemampuan yang telah dicapai anak, Adapun aspek yang menjadi penilaian perkembangan anak yaitu memahami mengapa pembelajaran dilakukan secara jarak jauh, dan pendidik memberikan deskripsi nilai seperti; berkembang sangat baik, berkembang sesuai harapan atau mulai berkembang dan bahkan belum berkembang. Hasil penilaian kemudian dikomunikasi kepada orang tua peserta didik dengan menggunakan media social (WhatsApp) secara pribadi antara pendidik dan orang tua peserta didik. Jika ada kekurangan maka akan 
dilakukan perbaikan pada pembelajaran selanjutnya.

Dokumen hasil pembelajaran selama di rumah menunjukkan bahwa anak mampu melakukan aktivitas yang biasanya dilakukan di sekolah. Hasil penilaian kemampuan kognitif anak pada penguasaan konsep mengenal sebab akibat; didapatkan bahwa peserta didik tidak membuat alsan mengapa anak tidak ke sekolah karena adanya virus Covid-19 tetapi hanya membuat alur jalan/jejak ke rumah; sementara anak kedua menunjukkan bahwa karena adanya Covid-19 maka dalam melakukan aktivitas harus menggunakan masker agar terhindar dari penularan coronavirus disease. Sehingga penilaian anak di saat berada di rumah menunjukkan penilaian berkembang sangat baik untuk aspek perkembangan kognitifnya, pada lingkup critical thinking yaitu anak mampu mengenal sebab akibat menyangkut dirinya. Anak akan mampu merasakan apa yang dialaminya apabila orang tua menjelaskan dengan perlahan (Mutmainnah, 2020).

Pelaksanaan kegiatan pembelajaran di rumah dilakukan oleh orang tua secara singkat dan jelas, dideskripsikan mengikuti langkah-langkah antara lain; kegiatan pertama, diawali dengan orang tua meminta anak untuk membaca doa belajar, kemudian orang tua dan anak bernyanyi bersama lagu pagiku cerahku, lagu Aceh ku saying dan lagu lainnya yang telah diajarkan di sekolah; kegiatan kedua, kegiatan inti dilakukan sesuai dengan rpph yang dibuat oleh guru PAUD, aktivitas anak mewarnai gambar virus Covid-19, menggunting sesuai pola gambar yang diberikan, bercerita, berdiskusi tentang kegiatan belajar di rumah; mengapa anak belajar di rumah, mengapa jika keluar dari rumah harus anak wajib menggunakan masker jika berada di luar rumah, serta kegiatan- kegiatan lainnya; kegiatan ketiga, kegiatan penutup dilakukan dengan cara recalling dan anak menunjukkan hasil karya atau aktivitasnya untuk direkam dan didokumentasikan oleh orang tua, selanjutnya kegiatan anak tersebut dilaporkan pada pendidik di media social (WhatsApp) grup satuan PAUD.

Strategi pendidik PAUD di rumah (orang tua) dalam melakukan pemberian stimulasi perkembangan dapat dilakukan dengan diskusi, baik dengan percakapan maupun secara tanya jawab (Mutmainnah, 2019). Strategi diskusi (percakapan/tanya jawab) digunakan untuk mengkomunikasikan tema atau subtema yang akan dipelajari oleh anak, misalnya topik bahasan "corona", orang tua menanyakan kepada anak mengenai topik corona, merangsang pengetahuan anak tentang corona, lalu orang tua menanyakan pemahaman anak tentang mengapa anak melakukan pembelajaran jarak jauh (daring), mengapa kalau keluar dari rumah harus menggunakan masker; dengan mengajak anak bercakap-cakap tercipta interaksi yang menyenangkan antara pendidik dengan anak sehingga konsep yang ingin disampaikan dalam topik bahasan tentang corona bisa dipahami oleh anak. Strategi keteladanan digunakan oleh pendidik PAUD di rumah untuk memberikan contoh terlebih dahulu kepada anak dalam melakukan sesuatu 
sebelum anak sendiri yang melakukannya (Retnaningrum, 2016)

Materi tentang covid-19 diberikan kepada anak usia dini untuk memberikan pemahaman tentang kondisi saat ini yaitu pembelajaran dilakukan di rumah. Materi tentang coronavirus disease sangat cocok untuk pengembangan kemampuan kognitif anak usia dini utamanya pada lingkup kemampuan critical thinking. Stimulasi perkembangan diberikan pada anak oleh pendidik melalui orang tua selama di rumah dengan pembelajaran yang asik, orang tua dapat memanfaatkan tepukan sambil bernyanyi. Dalam menggunakan penggunaan media, bernyanyi lagumerupakan alternatif yang sangat disenangi anak dalam proses bermain sambal belajar (Miranti, Engliana \& Hapsari, 2015). Metode bernyanyi sangat berpengaruh terhadap kecepatan anak dalam mengenal huruf dan angka di usia 5-6 tahun (Kamtini dan Sitompul, 2020).

\section{KESIMPULAN}

Strategi pendidik dalam mengasah kemampuan critical thinking anak berhasil dilaksanakan karena adanya keterlibat orang tua selama pembelajaran jarak jauh (daring). Pendidik melakukan tugasnya sebagai perencana atau membuat rencana pembelajaran harian, pendidik juga melakukan assessment kepada anak melalui kegiatan yang telah dilaporkan orang tua yang selama pandemi Covid19 ini bertambah perannya sebagai pendamping pendidik untuk menstimulasi perkembangan anak.

Hal yang paling utama dalam mengasah critical thinking anak melalui metode percakapan dan tanya jawab adalah anak dapat memahami adanya perubahan tempat dalam proses bermain sambil belajar, anak juga dapat memahami adanya pembatasan social (physical distancing) sehingga anak hanya dapat bermain di rumah, dan anak dapat memahami mengapa jika keluar rumah harus memakai masker, dan anak harus menggunakan atau mencuci tangan sebelum dan setelah bermain.

\section{DAFTAR PUSTAKA}

An Verburgh. (2019). Effectiveness Of Approaches To Stimulate Critical Thinking In Social Work Curricula, Journal: Studies in Higher Education, 44(5), $1-12$

doi.org/10.1080/03075079.2019. $\underline{1586336}$

Ayu, C. (2016). Meningkatkan Kemampuan Kognitif Anak dalam Kegiatan Membilang dengan Metode Bermain Media Kartu Angka pada Anak Usia 45 Tahun di TK Taqifa Bangkinang. Jurnal Obsesi: Jurnal Pendidikan Anak Usia Dini, 2(2), 60-71. https://doi.org/DOI https://doi.org/10.31004/obsesi.v $2 \mathrm{i} 2.43$

Creswell, J. W. (2015). Research Design Pendekatan Kualitatif, Kuantitatif, dan Mixed. Yogyakarta: Pustaka Pelajar.

Dewi, Iratna dan Suryana, D. (2020). Analisis Evaluasi Kinerja 
Pendidik Paud di PAUD Al Azhar Bukittinggi. Jurnal Obsesi: Jurnal Pendidikan Anak Usia Dini, 4(2), 1051-1059. https://doi.org/DOI https://doi.org/10.31004/obsesi.v $4 \mathrm{i} 2.465$

Diane $\mathrm{T}$ Dodge and Laura J Colker . (2001). The Creative curriculum for Early Chilhood. Washington: Teaching Strategies. Inc.

Fardiah, Murwani, Santosa dan Dhieni, N. (2020). Meningkatkan Kemampuan Kognitif Anak Usia Dini melalui Pembelajaran Sains. Jurnal Obsesi: Jurnal Pendidikan Anak Usia Dini, 4(1), 133-140. https://doi.org/DOI https://doi.org/10.31004/obsesi.v $4 \mathrm{i} 1.254$

Hewi, La, Muh. Saleh dan Wahyuni, R. (2019). Kelekatan (Attachment) Anak Usia Dini di Suku Laut Kabupaten Wakatobi. Jurnal Obsesi, 4(1), 406-415. https://doi.org/DOI: 10.31004/obsesi.v4i1.346

Hewi, L. dan S. (2019). Permainan Dadu pada Pengembangan Perilaku Prososial Anak di RA An-Nur Kota Kendari. JECED : Journal of Early Childhood Education and Development, 1(2), 115-128. https://doi.org/DOI:

https://doi.org/10.15642/jeced.v $1 \mathrm{i} 2.468$

Irma, C. N., Nisa, K., \& Sururiyah, S. K. (2019). Keterlibatan Orang
Tua dalam Pendidikan Anak Usia Dini di TK Masyithoh 1 Purworejo. Jurnal Obsesi: Jurnal Pendidikan Anak Usia Dini, 214-224(3), 1. https://doi.org/DOI: 10.31004/obsesi.v3i1.152

Jawati, R. (2013). Peningkatan Kemampuan Kognitif Anak Melalui Permainan Ludo Geometri di PAUD Habibul Ummi II. Spektrum: Jurnal Pendidikan Luar Sekolah (PLS), 1(1), 250-263. https://doi.org/DOI https://doi.org/10.24036/spektru mpls.v1i1.1537

Joni. (2016). Peningkatan Kemampuan Kognitif Anak dalam Kegiatan Berhitung dengan Permainan Dadu TK Mutiara Pekanbaru. Obsesi: Jurnal Pendidikan Anak Usia Dini, 2(1), 1-10. https://doi.org/DOI https://doi.org/10.31004/obsesi.v $2 \mathrm{i} 1.44$

Kamtini dan Sitompul, F. A. (2020). Pengaruh Metode Bernyanyi terhadap Kemampuan Mengingat Huruf dan Angka pada Anak Usia Dini. Jurnal Obsesi: Jurnal Pendidikan Anak Usia Dini, 4(1), 141-145. https://doi.org/DOI: 10.31004/obsesi.v4i1.295

Miranti, Ira,. Engliana \& Hapsari, F. S. (2015). Penggunaan Media Lagu Anak-Anak Dalam Mengembangkan Kemampuan Kosakata Bahasa Inggris Siswa 
Di Paud. Faktor Jurnal Ilmiah Kependidikan, 2(2), 167-172.

Mutmainnah. (2019). Lingkungan Dan Perkembangan Anak Usia Dini Dilihat Dari Perspektif Psikologi. Jurnal Gender Equality, 5(2), 15-32. DOI: http://dx.doi.org/10.22373/ equality.v5i2.5586

Mutmainnah. (2020). Pemikiran Progresivisme Dan Eksistensialisme Pada Pendidikan Anak Usia Dini (Studi Dalam Pembelajaran Bcct Pamela Phelps). Jurnal Gender Equality, 6(1), 13-26. DOI: http://dx.doi.org/10.22373/ equality.v6i1.5918

Norman K. Denzin \& Yvonna S. Lincoln (Eds.). (2009). Handbook Of Qualitative Research. In 1 (Dariyatno). Yogyakarta: Pustaka Pelajar.

Permatsari, Dewiana, Rohaeti, Euis Eti Sharina dan Westhisi, M. (2019). Meningkatkan Kemampuan Berpikir Logis Anak Usia Dini Melalui Metode Bernyanyi Pada Anak Kelompok B. Jurnal Ceria, 2(6), 230-236. https://doi.org/DOI: http://dx.doi.org/10.22460/ceria. v2i5.p230-236

Retnaningrum, W. (2016). Peningkatan Perkembangan Kognitif Anak Usia Dini melalui Media Bermain Memancing. Jurnal Pendidikan Dan Pemberdayaan Masyarakat, 3(2), 207-218.
https://doi.org/DOI:http://dx.doi. org/10.21831/jppm.v3i2.11284

Tatminingsih, S. (2019). Alternatif Stimulasi Kemampuan Kognitif melalui Penerapan Model Pembelajaran Berbasis Permainan Komprehensif. Jurnal Obsesi: Jurnal Pendidikan Anak Usia Dini, 3(1), 183-190. https://doi.org/DOI https://doi.org/10.31004/obsesi.v $3 \mathrm{i} 1.130$

Wahy, H. (2012). Keluarga Sebagai Basis Pendidikan Pertama Dan Utama. Jurnal Ilmiah Didaktika, 12(2), 245-258. https://doi.org/DOI: http://dx.doi.org/10.22373/jid.v1 $2 \mathrm{i} 2.451$

Yunita, H., Meilanie, S. M., \& F. (2019). Meningkatkan Kemampuan Berpikir Kritis melalui Pendekatan Saintifik. Jurnal Obsesi: Jurnal Pendidikan Anak Usia Dini, 3(2), 294-584. https://doi.org/DOI https://doi.org/10.31004/obsesi.v $3 \mathrm{i} 2.228$ 